\title{
The Cross-national Diffusion of Work Systems: Translation of Japanese \\ Operations in the UK
}

(Published in Organization Studies, 2004, 25: 209-228)

\begin{abstract}
This paper investigates the process of cross-national diffusion of work systems to affiliate firms of three Japanese MNCs in the UK. It examines the degree to which structural, cultural and control-related work systems of the source company are adopted by the recipient. The case studies highlight the interplay between institutional forces and organizational action through a process of work systems translation. The study is based on a systematic comparative analysis of the ways in which Japanese work systems are implemented and sustained in the given firms. It concludes that firms attempt to translate alternative work systems rather than submit to environmental pressures towards isomorphism. The process of diffusing work systems is not driven by pre-existing legacies alone. There is room for social action in that actors, through their interaction, contribute actively to shaping the work organization.
\end{abstract}

Descriptors: cross-national diffusion, Japanese work systems, translation, institutional theory 


\section{Introduction}

A multiplicity and diversity of institutional arguments have had in common the questioning of conventional organizational theories that rely on understanding organizations as essentially closed systems, working to a logic of efficiency, contextfree rational agency and/or 'one-best-way' in organizational structuring and operating (Djelic 1999). The dominant emphasis within institutional theory has been on structural isomorphism as an important consequence of both competitive and institutional processes (e.g. Meyer and Rowan 1977; DiMaggio 1988). Most of the institutional theorists view institutions as the source of stability and order (Scott 2001). There is the common belief that firms mimic a particular practice that they consider highly effective and efficient (e.g. DiMaggio and Powell 1983). In other words, organizations are driven to incorporate practices and procedures defined by prevailing rationalized concepts of organizational work that are institutionalized in society. This implies a set of 'best practices' for organizing work systems crossnationally where firms are treated as repositories of capabilities or competence, and knowledge is seen as an objectified commodity (cf. Teece and Pisano 1994).

The historical institutionalist variant of institutional theory, which the present study adopts, rejects the very idea of isomorphism and 'set[s] out to account for the peculiarities of a given national system of industrial production and for persistent structural differences across national boundaries' (Djelic 1999:7). It takes the social constructionist position that assumes that capabilities and preferences, that is the very nature of actors, cannot be understood except as part of some larger institutional framework. Social relationships and the impact that collective norms have on these relationships are examined in conjunction with the historical underpinnings and 
structural embeddedness of the given ties. This implies that the diffusion of work systems from one institutional context to another can be constrained by persistent differences in patterns of organizing, role of social structures and unintended outcomes of power struggles. Consequently, this study adopts the view that the diffusion process is a context-dependent activity which is shaped by the interrelated aspects of structure and management-worker relations and social networks in a process. It can be influenced by social pressures associated with the diversity in beliefs, practices and social expectations that can hinder the continuation of a practice (cf. Dacin et al. 2002). Tensions created by actors can lead to change in routines, rules and practices (Scott 2001).

Recent work has sought to address the relative inattention to the role of interest and agency in shaping action by acknowledging variation and change in institutional logics (see the special forum in AMJ, vol. 45, no. 1). Several studies have shown organizational members as active carriers of institutions (e.g. Townley 2002; Zilber 2002). In other words, actors perceive the meaning of institutions and infuse their actions with meaning based upon these perceptions. The present study contributes to this line of research by highlighting the dynamics of how alternative work systems are shaped by the adopter firm. The aim is to reflect the active process of accepting and approving alternative ways of operating, or infusing work systems with value (Kostova 1999) as it is observed in the attitudes of workers. Work systems are defined here as organizational practices that are the product of over three decades of continuous improvement in Japan, driven by people's knowledge, ideas and suggestions. They acquire a social meaning shaped by the institutional context, as they are enforced by public opinion, by knowledge legitimated through the 
educational system, by social prestige and by laws (Meyer and Rowan 1977). The study investigates the extent to which work systems diffused from 'highly coordinated' contexts to 'compartmentalized' institutional settings are accepted and put to use. It examines the degree to which institutional and organizational variation between Japan and the UK influences the attitudes of workers to Japanese work systems in the UK.

The following section discusses the institutional legacies of Japan and the UK and assesses the degree to which the institutional gap between the two influences the diffusability of work systems. In the third section, research design and data collection are discussed. The factors that are critical to the adopters' acceptance of and their role in translating work systems are presented in the fourth section. The final section presents the implications of the analysis for institutional theory.

\section{Institutional Legacies of Japan and the UK}

The dominant practices of firms in relation to work systems, reward systems and employee governance combine to form distinctive configurations that may be identified as a 'national business system' (cf. Whitley 1999).

The institutional profile, or the regulatory, cognitive and normative institutions (Scott 2001), that shape continuous improvement practices is one of high co-ordination in Japan. The highly co-ordinated national business system of Japan nurtures collectivist values and tightly-knit networks that encourage low strike activity, absenteeism and turnover. The norms governing trust and authority relations promote close links between managers and employees and allow for greater informal participation in 
decisions compared with 'western' plants (cf. Lincoln and Kalleberg 1990). The Japanese system of corporate management, such as employment stability and strong employee identification with the company, is seen as encouraging commitment to small-group activities (e.g. Tolich et al. 1999). Although Japan's employment practices are currently in a state of change, triggered by the Asian financial crisis of the early 1990s, they are still seen as having positive implications for participative, hands-on management; commitment to continuous improvement activities; team work and on-the-job training. There are few indicators that speak of any 'radical transformation' in the Japanese workplace at this point (Dirks et al. 2000).

By contrast, compartmentalized business systems discourage co-operation between business partners, including superordinates and subordinates. Management's desire for control over many key operating decisions and arm's-length relations between actors in Britain have reinforced a basic conflict model of the workplace in which strike activity, absenteeism and turnover have been common occurrences (cf. Lane 1996; McMillan 1996). Low employment security in connection with low investment in skills development hinders technical co-operation and trust formation.

Firms in compartmentalized business systems are more willing to invest major resources abroad to manage risk and uncertainty (Whitley 1999). As they are not dependent on other actors in a business network, they are more likely than cooperative ones to move assets across sectors and gain experience of managing diverse activities. Knowledge of such firms tends to be highly mobile given their inclination to standardize work procedures. By contrast, it is argued that firms in highly coordinated systems such as Japan find it difficult to diffuse firm-specific advantages to 
foreign affiliates, for they are strongly embedded in social networks of close cooperation and high interdependency (cf. Whitley 2001). In other words, highly localized, context-dependent work systems can be 'sticky' to diffuse to other institutional contexts (cf. Szulanski 1996).

Against this background, the study investigates the diffusion of continuous improvement schemes from Japan to the UK. It examines the active agency of UK affiliate firms in response to the diffusion of continuous improvement techniques such as team-based work organization and philosophies such as the values of team ethos and personal and cultural control or social investment that extends well beyond hierarchical principles. .

The institutional and organizational levels are addressed in an effort to consider the contextual embeddedness of work systems (see Figure 1).

Figure 1 about here

If the institutional context alone was addressed, then one would expect similar outcomes in the degrees of adoption of work systems in each firm. This would be to ignore any possible variation in the degree to which Japanese work systems are adopted across firms located in the same sector within a single country. In an attempt to capture this variation, a comparative study of two subsidiaries and a partner firm of three Japanese MNCs in the UK is carried out. The adoption of alternative work systems is understood here as representing a process of translating existing work 
systems to yield appropriated work systems or the blending of 'new' work systems with existing ones (cf. Clark 1987). Translation itself is understood as 'transformation, modification, change, renovation, and identity construction-a blending of the foreign and the local, the new and the old' (Tsui-Auch 2001:719).

\section{Research Design and Data Collection}

The study examines the diffusion of continuous improvement practices from a large and two medium-sized Japanese companies to their subsidiaries and partnering firm in the UK. Three qualitative case studies were conducted to attain a rigorous comparison of the diffusion process. It was felt that a systematic comparison of two subsidiary firms alone would not have provided diversity in the investigation of the likely influences on the adoption of alternative work systems. Three cases could yield more data than two cases where flow and configuration of events and reactions influencing a particular degree of adoption of work systems would become clear. A replication study was necessary whereby 'successive cases [could be] examined to see whether the new pattern matche[d] the one found earlier [in the first case study]' (Huberman and Miles 1998:195). Each case was selected to produce contrasting results but for predictable reasons to attain ‘theoretical replication' (cf. Yin 1994). According to Yin, at least four cases need to be designed to pursue two different patterns of theoretical replication. There was not a case similar to the Rover-Honda collaboration in the UK automotive sector, thus a fourth comparable site could not be added to the sample. The Rover-Honda collaboration was a complex alliance in the sense that $R \& D$, manufacturing, development and sourcing of parts were joint. The marketing and sales were the only separate areas (cf. Faulkner 1995). Thus the aim was to strike a balance between collecting data that allowed for rigorous analysis and avoiding data 
overload in the field, 'leading to the analysts thus missing important information, overweighing some findings, skewing the analysis’ (Huberman and Miles 1998:198).

The research sites were selected with the intention to include a brownfield subsidiary, a greenfield subsidiary and a technical collaboration site in an effort to address the need to incorporate the social context in which organizational practices are embedded. All of the three firms were located in the automotive manufacture sector. This sector lent itself to investigating the limits to diffusing 'Japanese best practices', for the UK automotive manufacture sector was heavily influenced by Japanese investment, particularly in the 1980 s.

The data were obtained from a field study employing 73 open-ended and semistructured interviews conducted between August 1998 and April 2000 at both the Japanese and UK companies. Information was sought on the meaning that continuous improvement techniques and philosophies had for UK adopters. Field observations and on-the-job discussions with operators guided the collection of data on the degree of adoption. Where the alternative practice is compatible with existing work systems, one would expect operators to accept the practice with little resistance. Consequently, the degree of adoption was measured as high where operators 'infused [alternative practices] with value beyond the technical requirements of the task at hand' (Selznick, 1957: 17).

Interviews were conducted with Japanese advisors, directors, UK team leaders, operators, electrical engineers, and managers across personnel and training, sales and marketing, product engineering, design and quality, finance, purchasing, logistics 
operations, the liaison office and manufacturing integration at the UK sites. Further information was gathered through one week's work experience in the two factories. Factory tours and interviews with Japanese electrical engineers and managers in international operations, product development, general affairs, quality assurance, corporate finance, engineering, corporate planning and control and design departments in Japan also served to enhance 'analytic realism' (Denzin and Lincoln, 1998).

Protocols (Yin 1994) incorporating schedules of company visits and members to be interviewed were developed. The majority of the interviews were taped and transcribed. Seven Rover, one Nissera UK and four Teniki UK interviews with British respondents were not taped as the conditions under which the interviews were conducted were not suitable for recording. Notes were taken during the interviews with Japanese participants owing to the language difficulty and the researcher's sensitivity to the trust-building mechanism inherent in the Japanese society where heavy emphasis is placed on goodwill trust that forms over time. Note-taking also allowed Japanese respondents to demonstrate the issue at hand by sketching it on paper.

The analysis of data reflects Djelic's (1998 based on John Stuart Mill's two-sided comparative method) two-step comparative historical analysis. It combines detailed case studies with systematic comparison. Detailed case studies ensure that 'historical and contextual singularities are not being disregarded', and systematic comparison 'allows for a significant theoretical leverage and represents a powerful tool, thus making generalization possible' (Djelic 1998:14). In-depth case studies highlighted 
the conditions underlying a given degree of adoption of Japanese work systems. Interview transcriptions and observation notes were scanned to generate a list of tentative sub-themes under the main themes of team-based structure, team ethos and personal and cultural control identified in the literature as having an impact on employee perceptions of work organization (see Saka 2003, where the practices are labelled as structural, cultural and control-related). Iterative loops of adding and amending sub-themes led to those that were identified as the most important in explaining the diffusion process. The triangulation of data and pattern-matching of key explanatory characteristics across the three cases validated themes. A 'method of difference' was adopted for comparing cases with different degrees of adoption. 'Instead of comparing different instances of a phenomenon, to discover in what they agree, this method compares an instance of its occurrence with an instance of its nonoccurrence, to discover in what they differ' (Mill 1974:391). By comparing divergent cases, the researcher was able to identify, in Djelic's term, 'bundles of conditions' that accounted for variations in outcomes. This approach reflects Eisenhardt's (1989) coupling of within-case data analysis with cross-case patterns for a more sophisticated understanding or Boyatzis' (1998) identification of themes within samples and their comparison across subsamples.

A valid picture of the phenomenon under investigation was attained through theoretical saturation (see Glaser and Strauss 1967 for a definition). In addition, the study adopted a multilevel approach, investigating work systems diffusion at the institutional and organizational levels. This was useful in saturating categories of incidents. It is argued that a multilevel approach is necessary to provide a 
representative account of a complex organizational phenomenon as that of crossnational diffusion of work systems (e.g. Kostova 1999).

One of the sites in the sample, Teniki UK (a pseudonym), represents an acquisition of a British firm by a Japanese car component manufacturer in 1996. The middle-sized company was run by a group of directors with limited sales and limited product types, and weak control prior to the acquisition. Teniki UK's senior management was replaced with customer-focused, quality-conscious team upon full Japanese ownership. This team was advised by six Japanese expatriates in technical and development, operations, sales and marketing areas.

The second site is a greenfield investment dating back to 1988. The company, Nissera UK (a pseudonym), employing 300 people in 1999 had 60 per cent Japanese employees in the early years of its foundation. This figure was reduced to the current 12 Japanese managers in senior director and manager roles in engineering and finance. They served to facilitate communication between the subsidiary and parent company. Over time, British managers filled in production roles that were previously occupied by the Japanese.

The final site in the sample is the technical collaboration between Rover and Honda, which was formed in 1978 as part of a strategy to increase economies of scale and to serve customers in the European market. Although there have been a series of collaborative projects over the course of Rover's partnership with Honda, this study focuses on the Rover 200/Honda Concerto (coded the R8/YY) project, as this constituted 'side-by-side' work rather than an arm's length relationship. The R8/YY project was seen by Rover engineers and senior managers as the most successful 
project in terms of the degree of collaboration, quality and process improvement, problem resolution and learning benefits. It also made a significant contribution to returning Rover to financial profitability and marked the highest level of introduction of Honda practices at Rover.

\section{Patterns of Work Systems Diffusion}

Findings show that practice adoption varies across foreign affiliates as a result of the institutional gap between the home and host countries, and the differences in organizational initiative in the active diffusion of alternative means of operating. Adopters at Nissera UK and the Rover-Honda collaboration were more successful in institutionalizing meaning to continuous improvement techniques and philosophies than those at Teniki UK. The amount of agency or Japanese expatriate managers' ability to alter rules was lower at Teniki UK.

\section{Continuous Improvement Techniques}

All three firms initiated a structural change to reduce levels of hierarchy in the organization. The previous structure at the two subsidiaries was set up along the line of superintendents, supervisors and hourly-paid workers. Superintendents, who reported to the factory production manager, had a wide span of control over hourlypaid workers. There was a significant change in authority relations to reduce costs and supervisory autonomy with the introduction of team leader and coach positions. At Rover, a project-based structure was adopted with the launch of the R8/YY project. The shift from a functional structure created an opportunity to build team spirit among the engineers. This was ingrained in the saying 'you have got a spirit and motivation of not wanting to let each other down. It gives you a bit more drive and impetus' (Rover design and development engineer). A project-based structure was seen as the 
best way to deliver a project, for technical problems could be solved accurately and quickly through consultation with a central group of expertise which could not be sustained under a functional structure.

Although the operators at the two subsidiaries did not perceive a major difference between the new and old organizational structure, those at Nissera UK were more receptive to accepting the change in authority relations. By the same token, the active adoption or the strong belief in and recognition of the value of a structural change was also evident among Rover engineers.

Before its acquisition in 1996, Teniki UK ran operations to low quality standards and efficiency levels and had poor management-worker relations.

In the past, it was a lot in the head. There was an autocratic process. 'I want you to do this, do that, because that person knows what is supposed to happen'. My approach is democratic. People need to know what is going on, so that they can feel part of the business and make their own decisions. (Operations manager at Teniki UK)

However, even after the acquisition, the lines of demarcation between functions and management and workers remained strong. The low skills level of the workforce and indirect involvement of Japanese expatriates in shop-floor activities challenged the acceptance of teamwork. Whereas at Nissera UK, the high concentration of Japanese expatriates in the early years after the company's establishment helped enhance UK operator skills. However, the original meaning of a team-based structure with fluid descriptions in Japan was translated by UK adopters. Team leaders who were perceived as occupying managerial positions by the operators and higher management 
had clearly defined responsibilities in the UK context: 'team leaders do not do the work. As long as they make sure the system is in, what comes out is efficiency, cost and quality' (Production manager at Nissera UK).

Adopters' role in translating a project-based structure at Rover could be observed in the greater control exercised by functional than project managers. There were conflicting interests between functional managers and project leaders, in that, the former preferred to avoid risks, whilst the latter wanted to take risks to develop innovative products. There was still a top-down approach, and Rover managers continued to be hands-off. Moreover, Rover had problems holding weekly meetings with every project leader because its engineers were based in three separate sites; Cowley, Canley and Longbridge. Although communication improved with the establishment of a design centre in Gaydon for all the engineers, the timing of the build phases still could not match that of Honda.

We agreed on a schedule. Rover could not understand this schedule, could not understand how to manage or carry out their own job. Honda sets up a project manager to manage the timing. They control the progress of the team. They also receive the services of a support function. (Japanese executive vice president of Honda R\&D Europe) Honda was able to operate a project-based structure much more effectively, 'delivering projects at the same time as having specialists' (Rover design director).

\section{Continuous Improvement Philosophies}

Teniki UK, Nissera UK and Rover found it difficult to develop and replicate 'esprit de corps' of continuous improvement activities. Their efforts to invest high degree of 
ownership of quality circles, discipline in the workplace and ' $5 \mathrm{C}$ ' housekeeping principles of classifying, clarifying, cleanliness, clean-up and custom in the hands of 'self-contained' teams met challenge.

There was a variation in team ethos across the three firms. For example, the low emphasis on training and control on the shop floor at Teniki UK created the space for particularly the older operators to work according to their own rules. They manipulated scrap rate figures under production pressures. 'Quality Assurance is called over when there is a supplier-related problem. If there is pressure to get the order out, then they will pass the item that I would normally scrap' (assembler at Teniki UK). Small group activity or Kaizen could not be successfully implemented at Teniki UK, for the training and development plan had not yet instilled a continuous improvement culture. The previous ownership focused on teaching skills that were related to an operator's immediate task rather than the overall production process. Although job training under Japanese management was typically provided internally and included consultation with staff, the UK adopters did not have 'the skills bottom up to top, we cannot achieve this sustainable continuous improvement within the plant' (Teniki UK operations manager). There was more emphasis on training engineers and greater focus on developing National Vocational Qualification (NVQ) levels than continuous improvement philosophies among operators. 'Teniki UK is located in an area popular for farming and armed forces. It is not an industrial location, so the education level is not that high. 60 per cent of the people have not more than three GCSEs [Graduate Certificate for Secondary Education]' (British personnel and training manager at Teniki UK). Furthermore, the four Japanese 
advisors who were in a position to train operators were preoccupied with start-up projects, hence, felt that they did not have the time to invest in training.

Although the acceptance and approval of team ethos was greater at Nissera UK than Teniki UK, it had not acquired the same symbolic and normative meaning as that at the Japanese parent company. The local management was perceived as being ineffective in running quality improvement ideas that were, in themselves, seen by the operators as beneficial: 'ideas are good but the outlook, seeing it through is crap (operator in cluster assembly at Nissera UK).

We were forced to go on this course [on quality circles]. They called it 'family circle'. It is a big joke. Everything is a joke. It could be better if they were straighter with us. As far as we are concerned, they have deceived us. They will start with something and if it does not suit them, they will change it. (Operator in cluster assembly at Nissera UK)

Operators did not subscribe to quality standards. The author's work experience on the shop floor showed that out-of-control quality measures were recorded as falling within tolerance levels. The low sense of responsibility for quality control processes was also observed in component testing. Operators found tests on fuel and temperature indicators that normally took seven minutes to complete too long, thus ended the tests prematurely. Although the quality control systems as Nissera UK were similar to those at the Japanese parent, '[O]ver the past two years, we have tended to go back to the Japanese parts. Every single part needs to meet quality standards. In the UK, the attitude is out of a million, surely there can be a few defects' (Japanese quality director at Nissera UK). 
At Rover, the psychological ownership of continuous improvement schemes was low until the initiation of the R8/YY project. Rover engineers could identify with and be involved in these schemes as more collaborative projects were carried out with Honda engineers. 'As the project went on, we were more and more subtly encouraged to go the Honda way on everything. In essence, we adopted our specifications to meet theirs at the end of the day' (principal electrical engineer at Rover). There was a willingness to exert considerable effort for the implementation, as well as a strong desire to continue the use of, Honda practices such as the gebba-kai process (i.e. quality circles adopted by engineers to solve problems at the end of each build phase) and formalized build phases. However, the gebba-kai practice was translated by the UK adopters to shorter meetings and fewer participants attending problem resolution sessions. Hence, there was the rise of a new configuration of meanings, resources and actors with the diffusion of the gebba-kai process. Although the intention was to have an internal and an external gebba-kai that lasted in total for two days as at Honda, Rover had 'changed it a little bit for the worst' (British senior manager in manufacturing integration at Rover)This was seen as the influence of people who had not been directly involved in joint engineering works for 6-12 months with Honda engineers.

The aim is to always arrive at a decision. I think if we followed it [ gebbakai] literally and the way some of the Honda engineers worked, then yes, we would always arrive at a decision because they would not leave without a decision. (Design and development engineer at Rover).

Rover's build phases were formalized to match Honda's evolutionary process in car development.

Learning from Honda was that you must go through a process of evolution and all the components that fit into the vehicle must be off-tool 
and off-process. One of the requirements that Honda laid down was that the more you practised, the better the product.

(Principal systems engineer at Rover)

However, Honda's methodical steps in delivering components contrasted with Rover's relatively ad hoc approach. Processes had been tested before, hence there were clear reasons as to why Honda engineers strictly abided by them. By contrast, Rover engineers tended 'to look for compromise and modify as appropriate or we feel we have to because we have money constraints' (principal systems engineer at Rover). Rover engineers found it difficult to work in a regimented manner and to abide by an agreed structure, lacking self-discipline to rigorously train people and test and stabilize processes (senior manufacturing integration at Rover.

Again we might not have the discipline that they adopt in terms of the PCR changes. PCRs are supposed to be all resolved and signed off at the [gebba-kai] event. But not everybody turns up. So we might not have the discipline to fully do it, but we still basically adopt it. (Principal electrical engineer at Rover)

At times Rover's adoption of alternative work methods was constrained by its long tradition of working with existing methods. This is exemplified by the differences in engine design requirements of Rover and Honda.

[Rover] had many connections in the engine. They installed engine ECU [Electronic Control Unit] under the bonnet. Engine harness was connected directly to the engine ECU. In Japan, we clamp that wire connection to prevent small vibrations from negatively affecting the ECU. Rover design did not incorporate this. The English have lots of experience [i.e. long tradition] of working without this clamp, so they 
asked 'why do we need it? It will increase cost'. At the end, we could not come to a compromise. (Principal engineer at Honda)

In addition to the variation in team ethos, the extent to which personal and cultural control was exercised through direct supervision and the use of expatriates at the three firms differed. Both Teniki UK and Nissera UK experienced high levels of control in technical and strategic affairs. However, Japanese expatriates were not visible in the management of factory activities at Teniki UK as they were at Nissera UK. They rather had a short-term outlook to developing capabilities owing to the financial pressure exerted on Teniki by a major car manufacturer. They emphasized clear-cut quantitative objectives in both strategic and operational decisions. Hence, there was an exercise of impersonal and technocratic control through output and planning (cf. Harzing, 2001).

Teniki [Japanese parent company] have pressure on them to put pressure on ourselves to make the returns faster than normal. In that case, we have had to have very stringent sort of budgetary control and cutting of budgets which would affect the long-term, that is the training budgets are not as good as they should be in my belief. (British operations manager at Teniki UK)

The majority of products at Teniki UK were designed around Japanese processes. They still require us to put in place best practice processes such as Ushaped cells, Single Minute Exchange of Dies (SMED), assembly cells where minimum stock levels of product are within reach, ergonomically designed. So they expect best practice. However, achieving some of the best practices is problematic. (British operations manager at Teniki UK) 
The heavy involvement of Japanese expatriates in technological and financial decisions was also evident at Nissera UK. The UK subsidiary was required to report to Nissera discussions on major managerial issues such as annual shareholder meetings and significant organizational changes. These were then discussed at the parent company within the framework of efficiency checks against investment. The high degree of involvement of Japanese managers in the diffusion of continuous improvement schemes contrasted with that at Teniki UK. Unlike that at the brownfield site, there was an emphasis on direct supervision and international transfer of managers or, in Harzing's (2001) terms, personal and cultural control at the greenfield site. However, Nissera's commitment to broad range and long-lasting effort to create the dedicated human and organizational capabilities decreased as its UK subsidiary failed to develop its own knowledge base and satisfactory financial results. First time I was in the UK, we brought know-how with documentation and information [such as quality standards, instruction manuals, quality control process charts and drawings]. Japan did not send any know-how after that. Their manufacturing is old and manual, so we cannot transfer know-how... Since 1993, Nissera UK has had bad profits. They could not manufacture anymore. (Japanese quality assurance manager at headquarters).

Japanese control at Rover was of personal and cultural nature as that at Nissera UK, but it was exercised through socialized, informal communication and management training rather than direct supervision owing to the nature of the collaboration. Rover's liaison officers facilitated information flow and helped forge good working 
relations with the Japanese. Engineers saw it as essential to build social relations based on trust, for 'you could have a discussion and there would be lots of nodding and agreeing, and it did not mean they agreed with what you were saying' (principal electrical engineer at Rover). The main concern was not whether information flowed back and forth, but whether the message was conveyed correctly and this depended on a working relationship with Honda engineers.

As you got to know more and more of their engineers, and they got to know us, we would be designing things in the pub afterwards with Honda engineers. We would draw a design on beer mat, pass it over to a Honda engineer. He would improve it and give it back to me. That would spark another idea in him and we shake on that. And then the next day, he would draw it up. We used to do a lot of our work like that. (Principal engineer at Rover)

\section{Discussion}

The findings at Teniki UK, Nissera UK and the Rover-Honda collaboration reveal that there are considerable differences in the diffusion of Japanese work systems owing to i) the institutional distance between home and host countries and ii) the role of interest and agency in shaping action.

At the institutional level, the operational autonomy provided to individuals in smallgroup activities strengthened by a sense of groupism in large firms in the Japanese automotive industry conflicts with the low worker discretion and sense of individualism that has traditionally strengthened the management hierarchy in the UK automotive industry. This is exemplified by Teniki UK: 'In Japan, employees are 
grateful for being given a project to do. However, in the UK, there is demarcation, unionization. Employees will ask "why ask me to do the project?"' (personnel and training manager at Teniki UK). The experience of developing interdependency, trust and shared knowledge is unique to a specific workplace, context and group of people (Cutcher-Gershenfeld et al. 1998). Thus, all three companies in the sample had difficulty imparting continuous improvement schemes by securing the commitment of all parties to the process owing to the institutional variation between the demands of a highly co-ordinated business system that encourages high interdependency and a compartmentalized business system that discourages collaboration and co-operation. The level of acceptance and approval of Japanese source companies' practices was high where habitual routines and pre-existing organizational setting were redesigned to integrate alternative work systems through company visits, cross-functional teamwork and the active participation of Japanese expatriates as boundary-spanning individuals. As Tsang (2001) shows, the coaching role of expatriate managers is crucial in cases where substantial cognitive change is required. For example, at Rover, staff in liaison roles dedicated to the development of the collaboration and joint meetings that allowed for co-ordination through lateral communication and negotiation rather than hierarchy were used as integration mechanisms. Nissera made heavy use of expatriates as a means to bring its UK subsidiary 'into the fold', that is to establish an organizational culture that aligned with the parent company's values (Jaeger 1983). In comparison, Teniki UK had the least number of Japanese expatriates available for training who tended to be hands-off in management. Hence, the resistance to alternative work systems was the greatest among Teniki UK operators. This was also, in part, associated with particularly older operators' preference for traditional British work organization of union activity and craftsmanship. 'We need 
the trade union down here to improve the work environment' (senior operator in Air Element at Teniki UK). In line with Tsang's (2001) argument, old routines hampered the diffusion of knowledge and discouraged the materialization or institutionalization of new ideas.

At the level of the organization, actors' role in shaping acquired knowledge was evident in the collective translation of meanings that were woven into a shared frame of reference (Hayes and Allison 1998). This alludes to the notion that the adoption process is a product of human activity that is socially defined (see Berger and Luckmann 1967). In line with Kostova and Roth's (2002: 229) argument, the 'depth of adoption within organizations is not necessarily driven by rational, efficiencybased decisions, but can be better explained in terms of the interpretive social processes through which employees build perceptions about the efficiency of a practice'. Action could not be habitualized in instances where the original meaning of path-dependent and firm-specific Japanese work systems could not be shared by the UK adopters. For instance, the process of enculturating team spirit was more difficult to articulate than change in authority relations along a team-based structure. Where practices were likely to have behavioural consequences such as in ways of working and inter-relating, or to initiate systemic change in Child and Rodrigues' (1996) terms, the adoption of work systems was more difficult. The creation of common meanings and identities was much easier where continuous improvement activities could be codified or structured into a set of identifiable rules and procedures such as Honda's project-based work organization rather than the sense of discipline required to carry out gebba-kais. These practices were basically techniques that did not require a major change to either people's behaviour or the pattern of relationships between 
them (cf. Child 1994). In accordance with Ackroyd et al.'s (1988) view, initiatives mediated by the orientation of British management were less straightforward in their effects. The Japanese emphasis on the human element of knowledge production at the operational level was not upheld by the UK managers who tended to emphasize knowledge that was easy to measure and control. The limited interaction through actions of individuals to synthesize knowledge in the UK business system (Hedlund and Nonaka 1993) tended to inhibit the extent to which continuous improvement philosophies could be infused with value at the three companies.

The cognitive process of interpreting actions and structures is highlighted in the blending of old and new practices. Alternative work systems are evaluated in the light of existing organizational practices and adopters' own assumptions concerning effective ways of operating. Foreign practices fight their way through a 'semipermeable organizational membrane, consisting of existing power networks, organizational culture and subcultures, in order to influence the existing set of organizational visions' (Doorewaard and van Bijsterveld 2001:61). There is editing or translation where 'successes' are reformulated and ascribed new meanings as they are diffused, that is ideas are recontextualized as they are disembedded from their original context. Rules of 'social control, conformism and traditionalism' direct the translation process (cf. Sahlin-Andersson 1996). The introduction of gebba-kai problem solving sessions exemplifies a translation process whereby 'external knowledge/artefacts/methods [were] "fused" with internal knowledge/procedures/systems' (Hislop et al. 1998:430). 
Historical institutionalism offers no amplification on how institutional forces interact with actors' social responses. Its emphasis on regularity and stability rarely builds in the role of the collective or individual actor. As is revealed by the case studies in this paper, the adoption of work systems can be 'blocked or facilitated by the nature of cultural infrastructure and the role of human agencies' (Loveridge 1987:193). The infusion of work systems with value is an active process involving actors' decisions to accept new ideas, where 'human agents... are creating and applying these symbols, interpreting these meanings and formulating, conforming to, disobeying and modifying these rules' (Scott 1994:60). Continuous improvement schemes were interpreted by UK operators upon their diffusion to a new setting. Their utilization or development required the active involvement of those workers who possessed it. The reconceptualization of knowledge took the form of a dynamic interaction among episodes of external acquisition of knowledge, its use by firms and the commitment by firms to the extent that the acquired knowledge assumed taken-for granted nature, or the attachment of a symbolic meaning and value by adopters to the practice as have the employees from the home country.

Findings demonstrate that not only broader institutional belief systems or logics, but also the interpretive schemes and interaction patterns of actors shape practices. The role of actors in shaping alternative systems is particularly visible where there is lack of management initiative in emphasizing training and in adopting a strong approach to discipline. For example, older workers at Teniki UK failed to fill in production timesheets on an hourly basis: 'I do it at the end of the day and take an average. It looks better that way' (senior operator in air element at Teniki UK). Whereas at Nissera UK, Japanese managers were hands-on with training and directly involved in 
factory activities. There was also the availability of financial and human resources at Nissera UK that were not readily accessible at Teniki UK. Teniki UK's financial flexibility was constrained for it had not yet achieved economies of scale and 57 per cent of its parent company's shares were held by a Japanese car manufacturer. The impact of key company and organizational factors, in addition to that of local institutional characteristics, are discussed in detail elsewhere (see Saka 2002).

At Rover, inter-personal, inter-firm networks, along with communication and joint decision-making mechanisms, were used for co-ordination and integration (Grandori and Soda 1995). The interpretation of Honda practices required heavy involvement in training to break 'method[s that were embedded] in individual expression' (manufacturing integration manager at Rover). There was a high level of training in quality skills and the car development system, as well as direct involvement in joint development processes with the Japanese. 'People transfer' through company visits served as a medium for trust building and learning (cf. Pucik 1996).

Where there was the presence of actors interacting intensely to diffuse work systems and heterogeneous-physical, financial and human—resources available to support continuous improvement techniques and philosophies such as that at Nissera UK and Rover, the adoption of alternative work systems was high (see figure 2).

Figure 2 about here

The degree of adoption of Japanese work systems at the UK adopter firms depended on the nature of the diffused practices, availability of physical, financial and human 
resources, and level of interaction between the actors involved, that is the role of the boundary-spanning individuals in the diffusion process. Actors, resources and activities in figure 2 are linked by social networks that have an important role in the acceptance and approval of practices (e.g. Newell and Clark 1990). Team-based structures, team ethos and the exercise of control through visibility in management are perceived as standardized models to be imitated in the absence of resources and actors aiming actively to diffuse both continuous improvement techniques and philosophies.

\section{Conclusion: Institutional Embeddedness of Organizations}

The findings at the three companies highlight the cultural and structural barriers to the diffusion of Japanese work systems. The diffusion process is examined in relation to, first, the institutional legacies that shape work systems, and second, the role of agency in determining how organizations interpret and respond to alternative practices. There is partial integration of generally conflicting practices that are embedded in institutional sources of organizational structure and culture. Teniki UK displayed a high level of resistance to Japanese work systems. By contrast, adopters at Nissera UK and Rover-Honda collaboration were relatively more receptive to alternative ways of operating owing to the availability of resources and the active role of boundary spanning individuals diffusing both continuous improvement techniques and philosophies.

The research findings contribute to historical institutionalism by highlighting the historical influences of a business system on the subsequent development of institutional arrangements as well as the apparent role of meanings connecting actors to actions. Studies in institutional theory predominantly allow little room for variety 
of response, for resistance, for efforts to change commonly held belief and established rules (Scott 2001). This study diverts the attention to the role of active agency. It demonstrates 'the capacity for individual and collective actors to act and pursue independent goals' (Hirsch 1997:1714). Highly context-dependent work systems are translated upon their diffusion to a different national business system. There is an enactment through social patterns of interaction in organizations. Organizations are not simply driven to incorporate practices and procedures defined by prevailing rationalized concepts of organizational work. As the case studies show, there is not a standard pattern of accepting alternative work systems. This contrasts isomorphism arguments where adopter firms copy a particular work that they perceive as best practice (e.g. DiMaggio and Powell 1983). Although there is evidence to suggest that 'path-dependent' distinctiveness of national forms of capitalist organizations still apply (Ferner 2000), firms are not as uniform within each capitalist system as is suggested by authors such as Orrù et al. (1991). Alternative work systems are edited, hence reflect interpretive processes, in accordance with situational circumstances and constraints as they are diffused.

\section{Note}

I would like to thank Muğla University, Turkey, for the financial support it has provided, as well as my respondents for showing genuine interest in and support for the research. 


\section{References}

Ackroyd, Stephen, Gibson Burrell, Mike Hughes, and Alan Whitaker

1988 'The Japanization of British industry?'. Industrial Relations Journal 19/1:1123.

Berger, Peter L. and Thomas Luckmann

1967 The social construction of reality. New York: Doubleday Anchor.

Boyatzis, Richard E.

1998 Transforming qualitative information: Thematic analysis and code development. Thousand Oaks, California: Sage Publications.

Child, John

1994 Management in China during the age of reform. Cambridge: Cambridge University Press.

Child, John and Suzana Rodrigues

1996 'The role of social identity in the international transfer of knowledge through joint ventures' in The politics of management knowledge. S. R. Clegg and G. Palmer (eds.), 46-68. London: Sage Publications.

Clark, Peter A.

1987 Anglo-American innovation. New York: Walter de Gruyter.

Cutcher-Gershenfeld, Joel, Michio Nitta, Betty J. Barret, Nejib Belhedi, Simon S. Chow, Takashi Inaba, Iwao Ishino, Wen-Jeng Lin, Michael L. Moore, William M. Mothersell, Jennifer Palthe, Shobha Ramanand, Mark E. Strolle, and Arthur C. Wheaton

1998 Knowledge-driven work: Unexpected lessons from Japanese and United States work practices. Oxford University Press: Japan Business and Economic Series.

Dacin, M. Tina, Jerry Goodstein and W. Richard Scott

2002 'Institutional theory and institutional change: Introduction to the special research forum'. Academy of Management Journal 45/1: 45-57.

Denzin, Norman K. and Yvonna S. Lincoln

1998 Collecting and Interpreting Qualitative Materials. London: Sage Publications.

DiMaggio, Paul J., and Walter W. Powell

1983 'The iron cage revisited: Institutional isomorphism and collective rationality in organizational fields'. American Sociological Review 48: 147-160.

Dirks, Daniel, Martin Hemmert, Jochen Legewie, Hendrik Meyer-Ohle, and Franz Waldenberger

2000 'The Japanese employment system in transition'. International Business Review 9/5: 525-553. 
Djelic, Marie Laure

1998 Exporting the American model: The post-war transformation of European business. Oxford: Oxford University Press.

Djelic, Marie Laure

1999 'From a typology of neo-institutional arguments to their cross-fertilization'. Research Paper, ESSEC.

Doorewaard, Hans, and Mark van Bijsterveld

2001 'The osmosis of ideas: An analysis of the integrated approach to IT management from a translation theory perspective'. Organization 8/1: 55-76.

Eisenhardt, Kathleen M.

1989 'Building Theories from Case Study Research'. Academy of Management Review 14/4: 532-550.

Faulkner, David

1995 International strategic alliances: Co-operating to compete. London: McGrawHill Book Company.

Ferner, Anthony

2000 'The embeddedness of US multinational companies in the US business system: Implications for HR/IR'. Occasional Paper Series, No. 61, Leicester Business School, De Montfort University.

Glaser, Barney G., and Anselm L. Strauss

1967 The discovery of grounded theory: Strategies for qualitative research. Chicago: Aldine.

Grandori, Anna, and Giuseppe Soda

1995 'Inter-firm networks: Antecedents, mechanisms and forms'. Organization Studies 16/2: 183-214.

Håkansson, Håkan

1986 Industrial technological development: A network approach. London: Croom Helm.

Harzing, Anne Wil K.

2001 'Of bears, bumble-bees and spiders: The role of expatriates in controlling foreign subsidiaries'. Journal of World Business 36/4: 366-379.

Hayes, John and Christopher W. Allinson

1998 'Cognitive style and the theory and practice of individual and collective learning in organizations'. Human Relations 51/7: 847-871.

Hedlund, Gunnar, and Ikujiro Nonaka

1993 'Models of Knowledge Management in the West and Japan' in Implementing strategic processes: Change, learning, and co-operation. P. Lorange, B. Chakravarthy, J. Roos and A. Van de Ven (eds.), 117-144. Oxford: Basil Blackwell. 
Hirsch, Paul M.

1997 'Review essay: Sociology without social structure: Neoinstitutional theory meets brave new world'. American Journal of Sociology 102: 1702-1723.

Hislop, Donald, Sue Newell, Harry Scarbrough, and Jacky Swan

1998 'Innovation and networks: Linking diffusion and implementation'. International Journal of Innovation Management 1/4: 427-448.

Huberman, A. Michael, and Matthew B. Miles

1998 'Data management and analysis methods' in Collecting and interpreting qualitative materials. N. K. Denzin and Y. S. Lincoln (eds.), 179-210. Thousand Oaks, California: Sage Publications.

Jaeger, Alfred M.

1983 'The transfer of organizational culture overseas: An approach to control in the multinational corporation'. Journal of International Business Studies 15: 91114.

Kostova, Tatiana

1999 'Transnational transfer of strategic organizational practices: A contextual perspective'. Academy of Management Review 24/2: 308-324.

Kostova, Tatiana, and Kendall Roth

2002 'Adoption of an organizational practice by subsidiaries of multinational corporations: Institutional and relational effects'. Academy of Management Journal 45/1: 215-233.

Lane, Christel

1996 'The social constitution of supplier relations in Britain and Germany: An institutionalist analysis' in The changing European firm: Limits to convergence. R. Whitley and P. H. Kristensen (eds.), 271-304. London: Routledge.

Lincoln, James R., and Arne Kalleberg

1990 Culture, control and commitment: A study of work organization and work attitudes in the United States and Japan. Cambridge, New York: Cambridge University Press.

Loveridge, Raymond

1987 'Social accommodations and technological transformations-The case of gender' in The manufacture of disadvantage: Stigma and social change. G. Lee and R. Loveridge (eds.), 176-197. Milton Keynes: Open University Press.

McMillan, Charles J.

1996 The Japanese industrial system, third edition. Berlin: Walter de Gruyter.

Meyer, John W., and Brian Rowan

1977 'Institutionalized organizations: Formal structure as myth and ceremony'. American Journal of Sociology 83/2: 340-363. 
Mill, John S.

1974 A system of logic ratiocinative and inductive: Being a connected view of the principles of evidence and the methods of scientific investigation. Toronto: University of Toronto Press.

Newell, Sue, and Peter Clark

1990 'The importance of extra-organizational network in the diffusion and appropriation of new technologies'. Knowledge: Creation, Diffusion, Utilization 12: 199-212.

Orrù, Marco, Nicole Woolsey Biggart, and Gary G. Hamilton

1991 'Organizational isomorphism in East Asia' in The new institutionalism in organizational analysis. W. W. Powell and P. J. DiMaggio (eds.), 361-389. Chicago: The University of Chicago Press.

Pucik, Vladimir

1996 'Strategic alliances, organizational learning and competitive advantage: The HRM agenda' in Knowledge management and organizational design. P. S. Myers (ed.), 151-165. Boston: Butterworth-Heinemann.

Sahlin-Andersson, Kerstin

1996 'Imitating by editing success: The construction of organization fields' in Translating organizational change. B. Czarniawska and G. Sevón (eds.), 6992. Berlin: Walter de Gruyter.

Saka, Ayse

2002 'Institutional limits to the internalization of work systems: A comparative study of three Japanese multinational companies in the UK'. European Journal of Industrial Relations 8/3: 251-275.

Saka, Ayse

2003 Cross-national appropriation of work systems: Japanese firms in the UK. Cheltenham, Gloucestershire: Edward Elgar, in print.

Sako, Mari

1992 Prices, quality and trust: Inter-firm relations in Britain and Japan. Cambridge: Cambridge University Press.

Selznick, Philip

1957 Leadership in administration. New York: Harper \& Row.

Scott, W. Richard

1994 'Institutions and organizations' in Institutional environments and organizations. W. R. Scott and J. W. Meyer (eds.), 55-80. Thousand Oaks, California: Sage.

Scott, W. Richard

2001 Institutions and organizations, second edition. Thousand Oaks, Sage Publications. 
Szulanski, Gabriel

1996 'Exploring internal stickiness: Impediments to the transfer of best practice within the firm'. Strategic Management Journal 17 (Winter Special Issue): $27-$ 43.

Teece, David and Gary Pisano

1994 'The dynamic capabilities of firms: An introduction'. Industrial and Corporate Change 3: 537-556.

Tolich, Martin, Martin Kenney, and Nicole Biggart

1999 'Managing the managers: Japanese management strategies in the USA'. Journal of Management Studies 36/5: 587-607.

Townley, Barbara

2002 'The role of competing rationalities in institutional change'. Academy of Management Journal 45/1: 163-179.

Tsang, Eric W. K.

2001 'Managerial learning in foreign-invested enterprises of China'. Management International Review 41/1: 29-51.

Tsui-Auch, Lai Si

2001 'Learning in global and local networks: Experience of Chinese firms in Hong Kong, Singapore, and Taiwan' in Handbook of organizational learning and knowledge. M. Dierkes, A. Berthoin Antal, J. Child and I. Nonaka (eds.), 716732. Oxford: Oxford University Press.

Whitley, Richard

1999 Divergent capitalisms: The social structuring and change of business systems. Oxford: Oxford University Press.

Whitley, Richard

2001 'How and why are international firms different? The consequences of crossborder managerial co-ordination for firm characteristics and behaviour' in The multinational firm: Organizing across institutional and national divides. G. Morgan, P. H. Kristensen and R. Whitley (Eds.), 27-68. Oxford: Oxford University Press.

Yin, Robert K.

1994 Case study research: Design and methods, second edition. Thousand Oaks, California: Sage Publications.

Zilber, Tammar B.

2002 'Institutionalization as an interplay between actions, meanings, and actors: The case of a rape crisis centre in Israel'. Academy of Management Journal 45/1: 234-254. 
Figure 1. Cross-national Diffusion of Work Systems

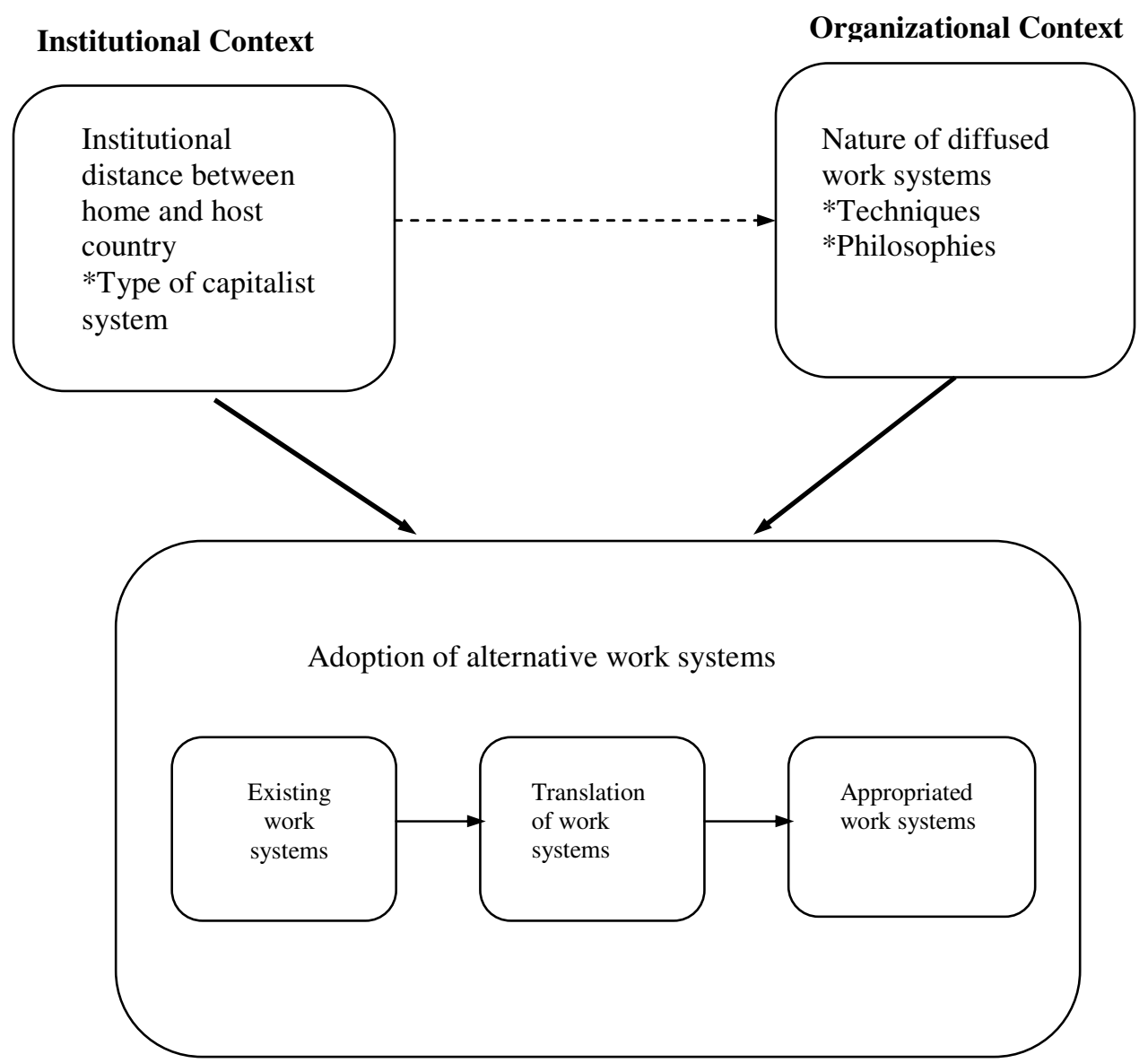

Source: Adapted from Kostova (1999:13) 
Figure 2. Network Framework Conducive to High Adoption of Work Systems

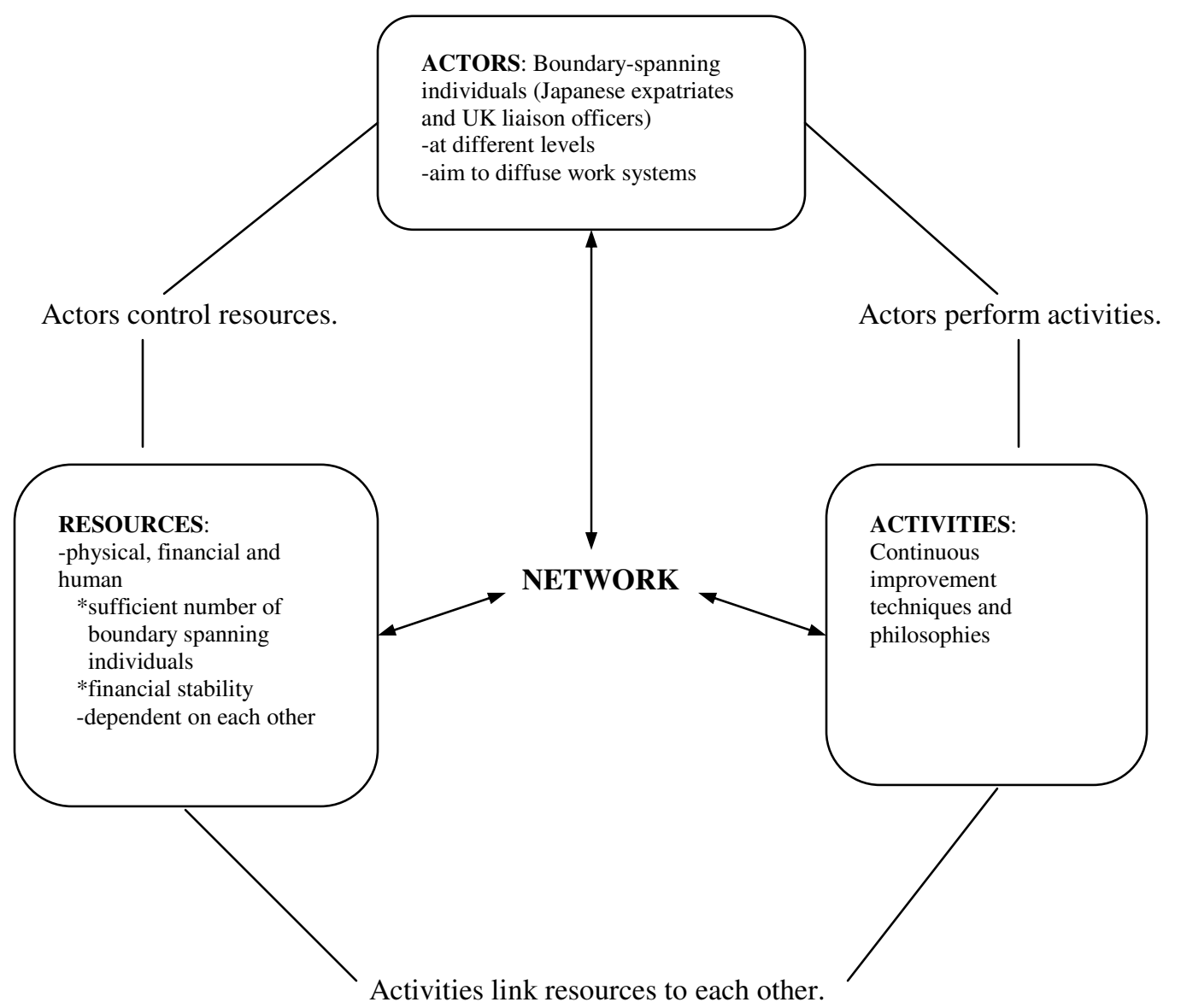

Source: Adapted from Håkansson (1986) 


\section{Biographical note:}

Ayse Saka is a Research Fellow at the International Economics and Business Department, University of Groningen, the Netherlands. She holds a $\mathrm{PhD}$ from Warwick Business School, University of Warwick. Her research interests include knowledge diffusion processes in cross-national settings and comparative study of organizations built within varieties of capitalism. Her current research focuses on the institutional and global effects on MNC learning within the European chemical industry.

Mailing Address: University of Groningen, Department of International Economics and Business, P.O. Box 800, 9700 AV Groningen, The Netherlands.

E-mail: A.SAKA@ECO.RUG.NL 